\title{
Molecular Detection of Toxoplasma gondii in Haemaphysalis Ticks in Korea
}

\author{
Ju Yeong Kim, You Shine Kwak, In-Yong Lee, Tai-Soon Yong* \\ Department of Environmental Medical Biology, Institute of Tropical Medicine, Arthropods of Medical Importance Resource Bank, \\ Yonsei University College of Medicine, Seoul 03722, Korea
}

\begin{abstract}
Toxoplasma gondii are intracellular protozoa that can cause neurological disease or death in fetuses and even in immunocompromised human adults. Ticks are recognized as vectors of many microorganisms including viruses, bacteria, and protozoa. Recent studies detected T. gondii in various tick species in many countries. In this study, we performed PCR detection of the T. gondii B1 gene from Haemaphysalis ticks collected from vegetation in 4 localities, Wonju, Gunsan, Miryang, and Yangsan, in Korea. We analyzed DNA from 314 ticks (268 Haemaphysalis longicornis and 46 Haemaphysalis flava) and the B1 gene of $T$. gondii was detected in 13 of these. The detection of $T$. gondii in ticks differed significantly by region $(P=0.021)$. T. gondii was detected in the following percentages of collected ticks: $3.7 \%(7$ of 189$)$ in Gunsan, 10\% (5 of 50) in Wonju, 16.7\% (1 of 6) in Yangsan, and 0\% (0 of 69) in Miryang. The detection of T. gondii in ticks was not associated with tick species or development stage. This is the first report of $T$. gondii detection in ticks in Korea. Our results provide important information necessary to understand toxoplasmosis transmission.
\end{abstract}

Key words: Toxoplasma gondii, Haemaphysalis, tick-borne disease, tick-borne pathogen, Korea

Toxoplasma gondii can cause severe neurological disease or death in developing human fetuses and in immunosuppressed patients; however, infected immunocompetent individuals are usually asymptomatic [1]. The seroprevalence of $T$. gondii in Korean people was reported as $5.6 \%$ in $1960,7.2 \%$ in 1983 , $7.7 \%$ in $1999,6.6 \%$ in $2000,6.7 \%$ in 2009 , and $8.6 \%$ in 2016 [2-7].

T. gondii has been detected in Korean wild animals such as feral cats, Chinese water deer, roe deer, and raccoon dogs [810], and in domesticated animals such as cattle, horses, rabbits, and dogs in Korea [11-14]. These animals include herbivores, which raises the possibility that bloodsucking arthropods such as ticks could transfer T. gondii [15]. Ticks are vectors of many microorganisms including viruses, bacteria, and protozoa.

Recently, T. gondii has been detected in various tick species [15], such as Dermacentor reticulatus and Ixodes ricinus in Poland [16-23], Amblyomma in the Republic of Chad [24], and

\footnotetext{
- Received 13 April 2020, revised 28 May 2020, accepted 3 June 2020.

*Corresponding author (tsyong212@yuhs.ac)

(c) 2020, Korean Society for Parasitology and Tropical Medicine

This is an Open Access article distributed under the terms of the Creative Commons

Attribution Non-Commercial License (https://creativecommons.org/licenses/by-nc/4.0) which permits unrestricted non-commercial use, distribution, and reproduction in any

medium, provided the original work is properly cited.
}

Haemaphysalis longicornis in China [25]. H. longicornis is the dominant tick species in Korea. In addition, many experiments have demonstrated the possibility of toxoplasmosis transmission via ticks [25-30].

In this study, we detected T. gondii DNA in Haemaphysalis ticks collected from vegetation in 4 localities in Korea. Ixodid tick H. longicornis is endemic to China, Korea, Japan, Russia, Australia, and New Zealand and is an important vector of protozoal parasites including Babesia ovata, Babesia gibsoni, Theileria sergenti, and Theileria mutans [31,32]. However, T. gondii has not been found in Korean ticks to date.

Ticks were collected from the vegetation by flagging. The tick collection areas were selected based on topographical, temperature, seasonal and weather aspects, among others. Ticks were collected from August 2014 to October 2016 in various Korean provinces to investigate possible regional characteristics: Wonju (Gangwon-do Province; 37.389545, 127.801770), Gunsan (Jeollabuk-do Province; 36.006237, 126.807751), Miryang (Gyeongsangnam-do Province; 35.475082, 128.780564), and Yangsan (Gyeongsangnam-do Province; 35.286111, 129.027625) (Fig. 1; Table 1). Species identification of collected ticks was performed by examination under a dissecting microscope according to Yamaguti et al. [33], and confirmed by PCR amplification of the tick DNA and sequencing of the 5.8S rRNA in- 
Table 1. Summary of Haemaphysalis ticks collected from vegetation in four localities in Korea

\begin{tabular}{|c|c|c|c|c|c|}
\hline Locality & $\begin{array}{c}\text { No. of } \\
\text { screened ticks }\end{array}$ & Stage & Species & $\begin{array}{l}\text { T. gondii positive } \\
\text { No. (\%) }\end{array}$ & Collection date \\
\hline \multirow[t]{2}{*}{ Gunsan } & 189 & $\begin{array}{c}\text { Adult: } 6 \\
\text { Nymph: } 52\end{array}$ & H. longicornis: 153 & 3.7 & 2014-August \\
\hline & & Larva: 131 & Haemaphysalis flava: 36 & & \\
\hline Wonju & 50 & $\begin{array}{c}\text { Adult: } 5 \\
\text { Nymph: } 45 \\
\text { Larva: } 0\end{array}$ & H. longicornis: 50 & 10 & 2015-July \\
\hline Miryang & 69 & $\begin{array}{c}\text { Adult: } 1 \\
\text { Nymph: } 2 \\
\text { Larva: } 66\end{array}$ & $\begin{array}{c}\text { H. longicornis: } 65 \\
\text { H. flava: } 4\end{array}$ & 0 & 2016-October \\
\hline Yangsan & 6 & $\begin{array}{l}\text { Adult: } 2 \\
\text { Nymph: } 4 \\
\text { Larva: } 0\end{array}$ & H. flava: 6 & 16.7 & 2015- October \\
\hline Total & 314 & $\begin{array}{c}\text { Adult: } 14 \\
\text { Nymph: } 103 \\
\text { Larva: } 197\end{array}$ & $\begin{array}{c}\text { H. longicornis: } 268 \\
\text { H. flava: } 46\end{array}$ & 4.1 & \\
\hline
\end{tabular}

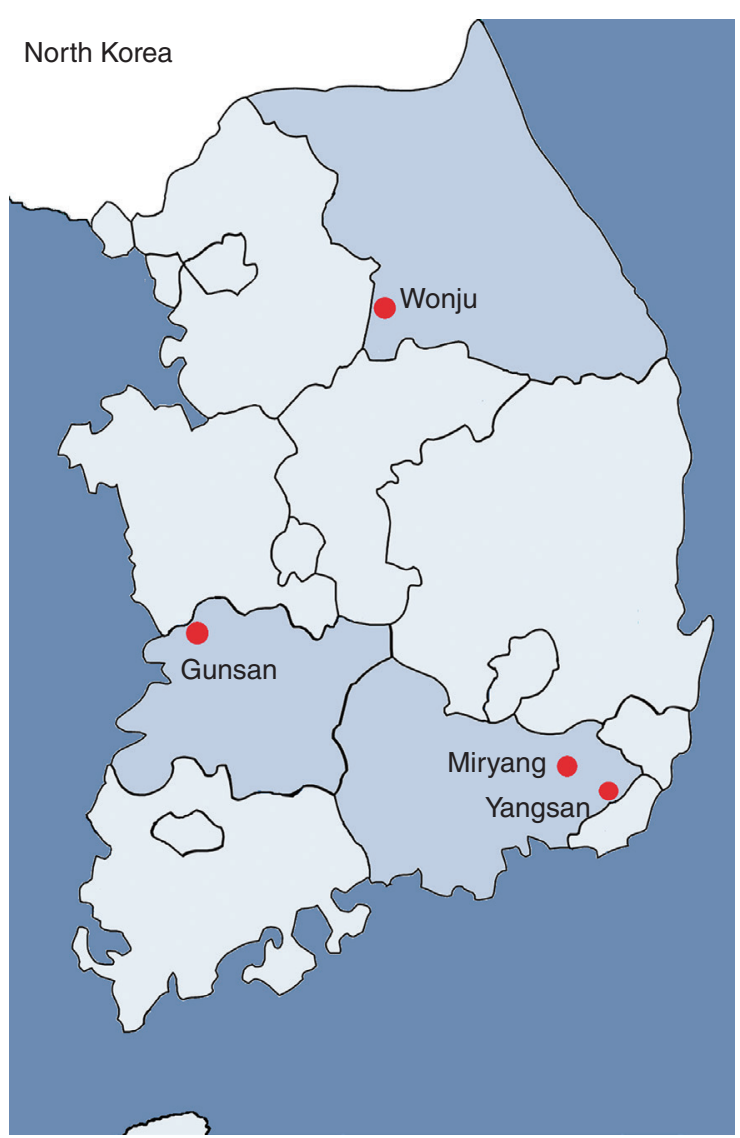

Fig. 1. Four localities of tick collection. Ticks were collected from the vegetation by flagging in Wonju, Gunsan, Miryang, and Yangsan in Korea.

ternal transcribed spacer 2 region using the primers HITS2-F (5'-GGTGCTCGAGACTCGTTTTG-3') and HITS2-R (5'-ATTC-
GCGGTTTACGAGAGAA-3') [34]. DNA was extracted from each collected tick using a NucleoSpin DNA Insect kit (Macherey-Nagel, Düren, Germany) according to the manufacturer's instructions, and stored at $-20^{\circ} \mathrm{C}$ until use. To detect the T. gondii $\mathrm{B} 1$ gene in ticks, nested PCR was performed with 2 primer pairs: S1 (5'-TGTTCTGTCCTATCGCAAC G-3') and AS1 (5'-ACGGATGCAGTTCCTTTCTG-3'), which amplify a 580-bp fragment; and S2 (5'-TCTTCCCAGACGTGGATTTC-3') and AS2 (5'-CTCGACAATACGCTGCTTGA-3'), which amplify a 530-bp fragment [35]. The PCR products were sequenced (Bionics Co., Seoul, Korea). A BLAST search was used to compare the obtained sequences to those available in GenBank (USA).

A total of 314 ticks from 4 regions were analyzed in this study, comprising 268 H. longicornis and 46 H. flava (Table 1). For 13 of these 314 ticks, agarose gel electrophoresis of PCR products revealed a band pattern at $530 \mathrm{bp}$ (Fig. 2), which indicated the presence of the T. gondii B1 gene. The DNA sequence of these PCR products showed greater than $99.7 \%$ identity with the published $B 1$ gene sequence of T. gondii (MH744807.1) (Table 2).

The detection of $T$. gondii in ticks differed significantly by collection locality $(P=0.021)$ (Table 3$)$. The T. gondii B1 gene was detected in 7 (3.7\%) of 189 ticks collected from Gunsan, in $5(10 \%)$ of 50 ticks collected from Wonju, and in one (16.7\%) of 6 ticks collected from Yangsan. T. gondii was not detected in the 69 ticks collected from Miryang.

The detection rate of T. gondii was 4.1\% (11 of 268) in $H$. longicornis and 4.3\% (2 of 46) in H. flava. This indicated there was no association between the species of tick and the detec- 
$\begin{array}{llllllllllllllllll}M & P & 1 & 2 & 3 & 4 & 5 & 6 & M & 7 & 8 & 9 & 10 & 11 & 12 & 13 & N\end{array}$

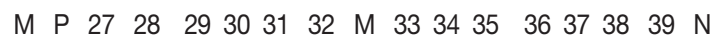
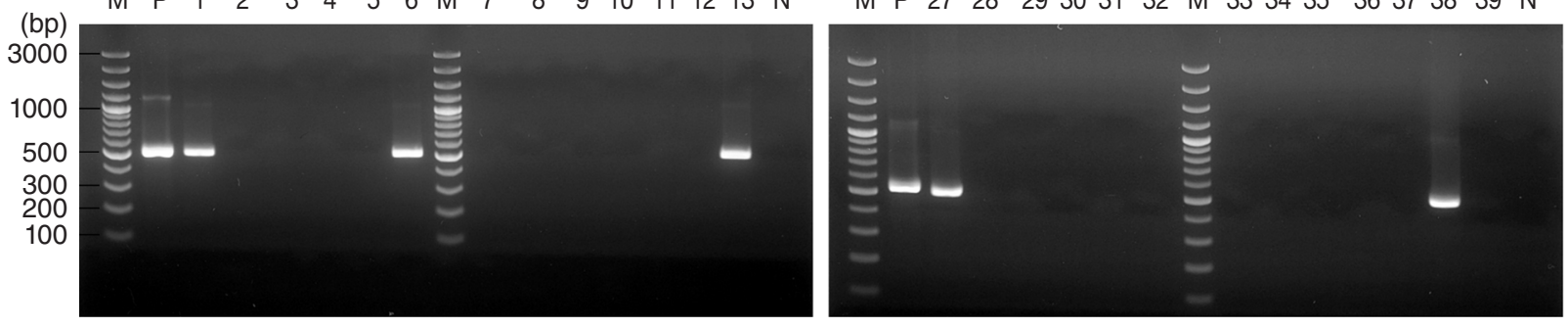

M P 131132133134135136 M 137138139140141142143 N

M P 183184185186 M 187188189 N
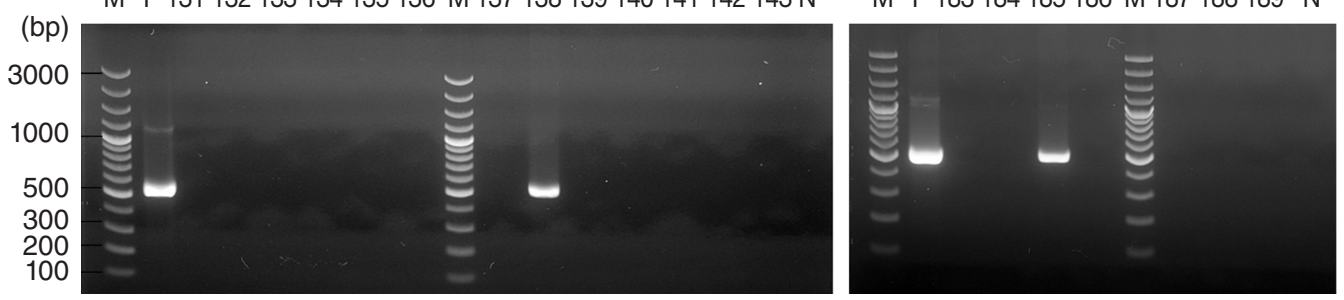

Fig. 2. Agarose gel electrophoresis results of Toxoplasma gondii B1 gene PCR products from Haemaphysalis ticks collected from Gunsan, Korea. PCR products from 7 of 189 tick DNA samples indicated the presence of T. gondii. M, marker; P, positive control (T. gondii DNA); N, negative control.

Table 2. Details of Toxoplasma gondii-positive Haemaphysalis ticks

\begin{tabular}{|c|c|c|c|c|c|}
\hline No. & Locality & Collection date & Tick species & $\begin{array}{l}\text { Development } \\
\text { stage }\end{array}$ & $\begin{array}{l}\text { Sequence identity (\%) to } \\
\text { B1 gene (MH744807.1) }\end{array}$ \\
\hline 1 & Gunsan & 2014-August & H. longicornis & Larva & 99.7 \\
\hline 2 & Gunsan & 2014-August & H. longicornis & Larva & 100 \\
\hline 3 & Gunsan & 2014-August & H. longicornis & Larva & 99.7 \\
\hline 4 & Gunsan & 2014-August & H. longicornis & Larva & 100 \\
\hline 5 & Gunsan & 2014-August & H. longicornis & Larva & 99.7 \\
\hline 6 & Gunsan & 2014-August & H. longicornis & Larva & 100 \\
\hline 7 & Gunsan & 2014-August & Haemaphysalis flava & Adult & 99.7 \\
\hline 8 & Wonju & 2015-July & H. longicornis & Nymph & 99.7 \\
\hline 9 & Wonju & 2015-July & H. longicornis & Nymph & 100 \\
\hline 10 & Wonju & 2015-July & H. longicornis & Nymph & 99.7 \\
\hline 11 & Wonju & 2015-July & H. longicornis & Nymph & 99.7 \\
\hline 12 & Wonju & 2015-July & H. longicornis & Adult & 99.7 \\
\hline 13 & Yangsan & 2015-October & H. flava & Nymph & 99.7 \\
\hline
\end{tabular}

tion of T. gondii (Table 3). The detection rates of T. gondii in tick adults, nymphs, and larvae were 14\% (2 of 14), 4.9\% (5 of 103), and 3.0\% (6 of 197), respectively. However, the detection rate of $T$. gondii among these 3 development stages was not statistically different $(P=0.113)$.

In this study, the detection rates of T. gondii in H. longicornis and $H$. flava were lower than the previously reported detection rate of T. gondii in H. longicornis (9.2\%; 39 of 422) from Qingdao, Shandong Province, China [25]. This study did not find $T$. gondii in Haemaphysalis larvae, but our results showed the presence of T. gondii in 3\% (6 of 197) of larvae. Previous studies have reported the presence of T. gondii in many tick species. In north-western Poland, 12.7\% of 259 Ixodes ricinus were infected with T. gondii [16]. The same study demonstrated that inoculation with homogenate of ticks caused toxoplasmosis in 44 of 60 mice [16]. T. gondii DNA was detected in $2.8 \%$ of adult $I$. ricinus in eastern Poland [17], and in $64.9 \%$ of I. ricinus adults and nymphs in Upper Silesia, Poland [18]. T. gondii DNA was also found in 3\% (52 of 1,737) of I. ricinus feeding on ponies and in $10.2 \%$ (38 of 371 ) of $I$. ricinus from vegetation including 7 larvae [19]. T. gondii DNA was detected in 3.2\% (21 of 664) of adult Dermacentor reticulatus, a human-biting tick, collected from vegetation [20].

Several laboratory experiments have demonstrated the trans- 
Table 3. Association of variables related to Toxoplasma gondiipositive of ticks

\begin{tabular}{lrrr}
\hline & $\begin{array}{c}\text { No. of } \\
\text { screened }\end{array}$ & $\begin{array}{c}\text { T. gondii } \\
\text { positive (\%) }\end{array}$ & P-value \\
\hline Locality & & & 0.021 \\
Gunsan & 189 & 3.7 & \\
Wonju & 50 & 10 & \\
Miryang & 69 & 0 & \\
Yangsan & 6 & 16.7 & \\
$\quad$ Total & 314 & 4.1 & \\
Tick Species & & & 1.000 \\
Haemaphysalis longicornis & 268 & 4.1 & \\
Haemaphysalis flava & 46 & 4.3 & \\
$\quad$ Total & 314 & 4.1 & \\
Stage & & & 0.113 \\
$\quad$ Adult & 14 & 14.3 & \\
Nymph & 103 & 4.9 & \\
Larva & 197 & 3.0 & \\
$\quad$ Total & 314 & 4.1 & \\
\hline
\end{tabular}

${ }^{a} P$-values were calculated using chi-square or Fisher exact tests.

mission of toxoplasmosis by ticks. Amblyomma americanum, Dermacentor variabilis, and Dermacentor andersoni transmitted $T$. gondii by blood feeding in the laboratory animals [26]. D. andersoni showed transovarial transmission of T. gondii to offspring [26]. I. ricinus can transmit $T$. gondii to mice through blood feeding [27]. T. gondii was reported to survive in the body of $H$. longicornis for more than 10 days $[25,28]$ and $T$. gondii was transmitted to the host by ingestion, but not by blood-feeding, of infected ticks [25].

T. gondii has previously been detected in wild animals and livestock in Korea. T. gondii oocysts were found in $0.89 \%$ (5 of 563) of feral cat feces [8]. T. gondii IgG test results were positive in $12 \%$ ( 6 of 50) feral cats [9]. A PCR assay indicated the presence of T. gondii in $47.2 \%$ (50 of 106) of feral cats and 46.3\% (64 of 138) of dogs [14]. The incidence of T. gondii seropositivity was $10.8 \%$ in Chinese water deer, $4.3 \%$ in raccoon dogs, $16.7 \%$ in roe deer [10]. Furthermore, the T. gondii $\mathrm{B} 1$ gene was detected in the blood of $16.2 \%$ (23 of 142) of rabbits from breeding farms in Korea [11]. The incidence of $T$. gondii seropositivity was $0.5 \%$ ( 3 of 568) in cattle [12], and 2.9\% (24 of 816 ) and $2.6 \%$ (5 of 191) in 2 studies on horses [13,36].

It is well known that $T$. gondii infection can be caused by contact with T. gondii-oocyst-shedding cats and ingestion of $T$. gondii-contaminated food [37]. However, we suggest the possibility that the tick is a potential vector for transmission of $T$. gondii, based on the worldwide presence of T. gondii in ticks, experimental evidence of toxoplasmosis transmission by ticks, and cases of T. gondii infection in several herbivorous wild animals and livestock [15].

This is the first report of T. gondii detection in ticks in Korea. T. gondii was found in all lifecycle stages of both $\mathrm{H}$. longicornis and $H$. flava ticks collected from vegetation in Gunsan, Wonju, and Yangsan. This study provides important information necessary to understand toxoplasmosis transmission. We suggested a new transmission cycle of $T$. gondii as vector-borne in wild and domestic animals.

\section{ACKNOWLEDGMENTS}

This study was supported by a National Research Foundation of Korea (NRF) grant funded by the Korean Government (Ministry of Education, Science and Technology; grant no. 2019R1A2B5B01069843).

\section{CONFLICT OF INTEREST}

The authors have no conflicts of interest to declare.

\section{REFERENCES}

1. Tenter AM, Heckeroth AR, Weiss LM. Toxoplasma gondii: from animals to humans. Int J Parasitol 2000; 30: 1217-1258.

2. Soh CT, Lee SJ, Ahn Y. Latent infection by Toxoplasma gondii in Korea. Yonsei Med J 1960; 1: 52-54.

3. Kim TJ, Choi WY. Toxoplasma antibody titer by indirect latex agglutination test in Seoul area. J Catholic Med Coll 1983; 36: 133-137.

4. Kook J, Lee HJ, Kim BI, Yun CK, Guk SM, Seo M, Park YK, Hong ST, Chai JY. Toxoplasma gondii antibody titers in sera of children admitted to the Seoul National University Children's Hospital. Korean J Parasitol 1999; 37: 27-32.

5. Yang HJ, Jin KN, Park YK, Hong SC, Bae JM, Lee SH, Choi HS, Hwang HS, Chung YB, Lee NS, Nam HW. Seroprevalence of toxoplasmosis in the residents of Cheju island, Korea. Korean J Parasitol 2000; 38: 91-93.

6. Shin DW, Cha DY, Hua QJ, Cha GH, Lee YH. Seroprevalence of Toxoplasma gondii infection and characteristics of seropositive patients in general hospitals in Daejeon, Korea. Korean J Parasitol 2009; 47: 125-130.

7. Jung BK, Song H, Kim MJ, Cho J, Shin EH, Chai JY. High Toxoplasma gondii seropositivity among brain tumor patients in Korea. Korean J Parasitol 2016; 54: 201-204.

8. Ahn KS, Ahn AJ, Park SI, Sohn WM, Shim JH, Shin SS. Excretion of Toxoplasma gondii oocysts from Feral Cats in Korea. Korean J Parasitol 2019; 57: 665-670.

9. Kim SE, Choi R, Kang SW, Hyun C. Prevalence of Toxoplasma 
gondii infection in household and feral cats in Korea. J Parasit Dis 2017; 41: 823-825.

10. Hong SH, Kim HJ, Jeong YI, Cho SH, Lee WJ, Kim JT, Lee SE. Serological and molecular detection of Toxoplasma gondii and Babesia microti in the blood of rescued wild animals in Gangwon-do (Province), Korea. Korean J Parasitol 2017; 55: 207-212.

11. Shin HG, Lee SE, Hong SH, Kim SM, Choi YK, Park HJ, Seo KW, Song KH. Prevalence of Toxoplasma gondii infection in rabbits of Korea by serological tests and nested polymerase chain reaction. J Vet Med Sci 2013; 75: 1609-1613.

12. Oh J, Lee SH, Lee SJ, Kim YH, Park SC, Rhee MH, Kwon OD, Kim TH, Kwak D. Detection of antibodies against Toxoplasma gondii in cattle raised in Gyeongbuk Province, Korea. J Food Prot 2016; 79: 821-824.

13. Lee SH, Lee SE, Seo MG, Goo YK, Cho KH, Cho GJ, Kwon OD, Kwak D, Lee WJ. Evidence of Toxoplasma gondii exposure among horses in Korea. J Vet Med Sci 2014; 76: 1663-1665.

14. Lee JY, Lee SE, Lee EG, Song KH. Nested PCR-based detection of Toxoplasma gondii in German shepherd dogs and stray cats in South Korea. Res Vet Sci 2008; 85: 125-127.

15. Ben-Harari RR. Tick transmission of toxoplasmosis. Expert Rev Anti Infect Ther 2019; 17: 911-917.

16. Sroka J, Wójcik-Fatla A, Zwoliński J, Zajac V, Sawczuk M, Dutkiewicz J. Preliminary study on the occurrence of Toxoplasma gondii in Ixodes ricinus ticks from north-western Poland with the use of PCR. Ann Agric Environ Med 2008; 15: 333-338.

17. Sroka J, Chmielewska-Badora J, Dutkiewicz J. Ixodes ricinus as a potential vector of Toxoplasma gondii. Ann Agric Environ Med 2003; 10: 121-123.

18. Asman M, Solarz K, Cuber P, Gąsior T, Szilman P, Szilman E, Tondaś E, Matzullok A, Kusion N, Florek K. Detection of protozoans Babesia microti and Toxoplasma gondii and their co-existence in ticks (Acari: ixodida) collected in Tarnogórski district (Upper Silesia, Poland). Ann Agric Environ Med 2015; 22: 80-83.

19. Adamska M, Skotarczak B. Molecular evidence for Toxoplasma gondii in feeding and questing Ixodes ricinus ticks. Ticks Tick Borne Dis 2017; 8: 259-261.

20. Wojcik-Fatla A, Sroka J, Zajac V, Sawczyn A, Cisak E, Dutkiewicz J. Toxoplasma gondii (Nicolle et Manceaux, 1908) detected in Dermacentor reticulatus (Fabricius) (Ixodidae). Folia Parasitol (Praha) 2015; 62: 2015-2055.

21. Skotarczak BI. The role of ticks in transmission cycle of Toxoplasma gondii. Ann Parasitol 2016; 62: 185-191.

22. Adamska M, Skotarczak B. Molecular evidence for Sporozoa pathogens in feeding and questing Ixodes ricinus ticks. Ticks Tick Borne Dis 2017; 8: 259-261.

23. Sroka J, Szymanska J, Wojcik-Fatla A. The occurrence of Toxoplasma gondii and Borrelia burgdorferi sensu lato in Ixodes ricinus ticks from east Poland with the use of PCR. Ann Agric Environ Med 2009; 16: 313-319.

24. Gidel R, Provost A. Isolement de Toxoplasma gondii chez des Ixo- didés du genre Amblyomma naturellement infectés. Ann Inst Pasteur (Paris) 1965; 109: 613-616 (in French).

25. Zhou Y, Zhang H, Cao J, Gong H, Zhou J. Epidemiology of toxoplasmosis: role of the tick Haemaphysalis longicornis. Infect Dis Poverty 2016; 5: 14

26. Woke PA, Jacobs L, Jones FE, Melton ML. Experimental results on possible arthropod transmission of toxoplasmosis. J Parasitol 1953; 39: 523-532.

27. Deryło A, Toś-Luty S, Dutkiewicz J, Umiński J. Participation of Ixodes ricinus L. ticks in the biology and transmission of Toxoplasma gondii. Wiad Parazytol 1978; 24: 585-595 (in Polish).

28. Tanaka T, Maeda H, Galay RL, Boldbattar D, Umemiya-Shirafuji R, Suzuki H, Xuan X, Tsuji N, Fujisaki K. Tick longicin implicated in the arthropod transmission of Toxoplasma gondii. J Vet Sci Technol 2012; 3: 3633-3640.

29. Havlik O. Experimental transmission of toxoplasmosis by tick Ornithodorus moubata. Cas Lek Cesk 1951; 90: 1516-1518.

30. Jagow M, Hoffmann G. Experiments on the transmission of Toxoplasma gondii in various developing stages of Ornithodoros moubata. Z Parasitenkd 1970; 33: 246-251 (in German).

31. Hoogstraal H, Roberts FH, Kohls GM, Tipton VJ. Review of haemaphysalis (Kaiseriana) longicornis Neumann (Resurrected) of Australia, New Zealand, New Caledonia, Fiji, Japan, Korea, and Northeastern China and USSR, and its parthenogenetic and bisexual populations (Ixodoidea, Ixodidae). J Parasitol 1968; 54: 1197-1213.

32. Galay RL, Maeda H, Aung KM, Umemiya-Shirafuji R, Xuan X, Igarashi I, Tsuji N, Tanaka T, Fujisaki K. Anti-babesial activity of a potent peptide fragment derived from longicin of Haemaphysalis longicornis. Trop Anim Health Prod 2012; 44: 343-348.

33. Yamaguti N, Tipton VJ, Keegan HL, Toshioka H. Ticks of Japan, Korea, and the Ryukyu islands. Brigham Young Univ Sci Bull Bio Ser 1971; 15: 1-227.

34. Oh JY, Moon BC, Bae BK, Shin EH, Ko YH, Kim YJ, Park YH, Chae JS. Genetic identification and phylogenetic analysis of Anaplasma and Ehrlichia Species in Haemaphysalis longicornis collected from Jeju Island, Korea. J Bacteriol Virol 2009; 39: 257267.

35. Alfonso Y, Fraga J, Jiménez N, Fonseca C, Dorta-Contreras AJ, Cox R, Capó V, Bandera F, Pomier O, Ginorio D. Detection of Toxoplasma gondii in cerebrospinal fluid from AIDS patients by nested PCR and rapid identification of type I allele at B1 gene by RFLP analysis. Exp Parasitol 2009; 122: 203-207.

36. Gupta GD, Lakritz J, Kim JH, Kim DY, Kim JK, Marsh AE. Seroprevalence of Neospora, Toxoplasma gondii and Sarcocystis neurona antibodies in horses from Jeju island, South Korea. Vet Parasitol 2002; 106: 193-201.

37. Almería S, Calvete C, Pagés A, Gauss C, Dubey JP. Factors affecting the seroprevalence of Toxoplasma gondii infection in wild rabbits (Oryctolagus cuniculus) from Spain. Vet Parasitol 2004; 123: $265-270$. 


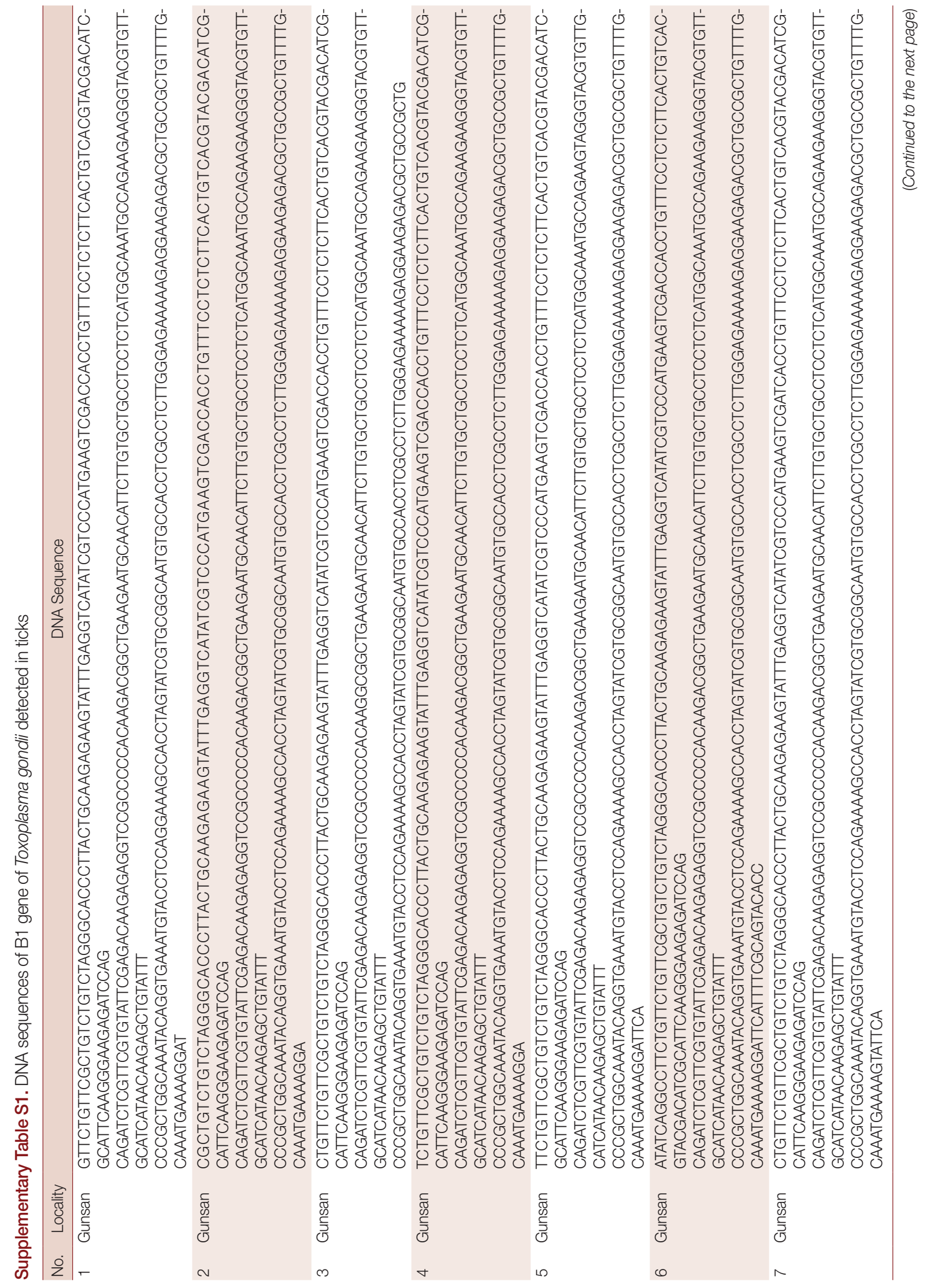




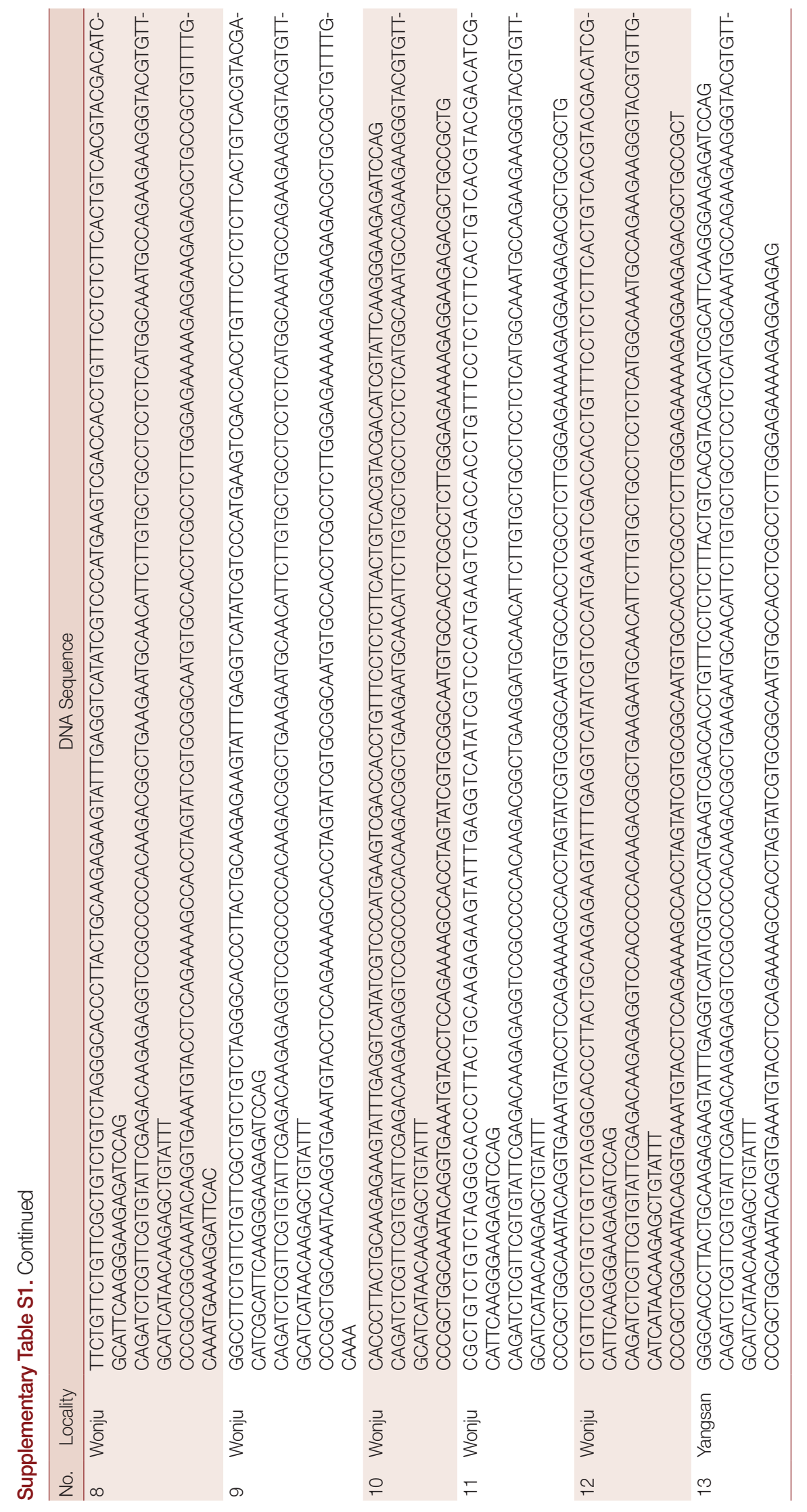


